\title{
Implementation of Character Education in Fostering Elementary School Students in Indonesia
}

\author{
Yuhanis $^{1}$, Yasir Arafat ${ }^{2}$, Artanti Puspitasari ${ }^{3}$ \\ ${ }^{1}$ SD Negeri 17 Gelumbang, ${ }^{2,3}$ Universitas PGRI Palembang \\ *e-mail: yuhanisssanis@gmail.com
}

\begin{abstract}
This paper is a qualitative research, which aimed at providing an overview of the implementation of character education in fostering students at SD Negeri 17 Gelumbang. The subjects in this study were the principal, teachers, and students. Data collection were carried out through interviews, observation and documentation. Data were analyzed by reduction, presentation, and conculsion. The results concluded that the implementation of character values at SD Negeri 17 Gelumbang is carried out by internalizing character values into compulsory subject matter, namely Islamic Religious Education, Citizenship Education, Indonesian Language, Mathematics, Social Sciences, Natural Sciences, and Physical Health Education through a learning process. The implementation of character values at SD Negeri 17 Gelumbang is carried out programmatically.
\end{abstract}

Keywords: Integration and internalization; Early education; Character education $(1)$ Licensees may copy, distribute, display and perform the work and make derivative works and remixes based on it only if they give the author or
licensor the credits (attribution) in the manner specified by these. Licensees may copy, distribute, display, and perform the work and make derivative works and remixes based on it only for non-commercial purposes.

\section{INTRODUCTION}

Education directs people to a better life, regarding the degree of humanity to achieve their life goals (Kompri, 2015). Education has a very big role as a center of excellence to prepare human character in facing global challenges. This is in line with Oberman's statement that "Indonesia will be a very strong nation in all sectors in 2045 or 100 years after its independence day. This is supported by Indonesia's economy growth. Already the 16thlarge economy in the world, Indonesia has the potential to be 7th-biggest by 2030 (Safitri, 2015).

Thus, education needs to prepare quality, competitive and creative students. The delivery of education in Indonesia must be evenly distributed and oriented towards future challenges. This implementation is supported by good management by policy makers and education practitioners, so that the implementation of national education can be achieved optimally in accordance with the objectives of national education as stated in Law number 20 of 2003 concerning the national education system article 3 .

Education in Indonesia is oriented to creating a generation that is broad-minded through optimizing each student's potential and forming human character such as faith, noble character, physically and mentally healthy, independent, creative, democratic and responsible. But the facts are inconsistent, students at this time, do not have manners, like brawls, drink alcohol, narcotics, and speeding on the highway. The phenomenon above suggests that character education is very urgent to be applied, especially in Early Childhood Education to Elementary School, because students at this time need moral education that is able to translate abstract principles about right and wrong, so that it can be preventive in overcoming attitude problems (Judiani, 2010). This is in line with Hurlock that moral development in early childhood is still at a low level, so it is not yet able to apply abstract 
principles of right and wrong (Fitria et al., 2019; Kristiawan et al., 2019).

Character education in elementary schools should get more attention to form a strong foundation of noble morals for students (Kristiawan, 2015b). This is done so that students have an awareness of the importance of the values of goodness and have a commitment to always do good in further education and in everyday life, in line with Rohendi that character education must start from elementary school because if the character is not formed early, it will be difficult to change someone's character (Sayer et al., 2018). Optimization in education will shape the personality of students who are good at sorting and choosing associations, actions, and actions in accordance with applicable norms. This is in line with what was conveyed by the $7^{\text {th }}$ President of the Republic of Indonesia that during Indonesia's presidential election campaign last year, Joko Widodo often spoke of the country's need "mental revolution" a paradigm shift in thinking that the Indonesian people and government would need to make in order to achieve what he called a free, fair and prosperous Indonesia".

These changes are directly proportional to the experiences of students in social realities that shape their characters. Parents, teachers, and friends will provide new experiences and knowledge related to true values and one that will internalize it into a character in oneself. This is in line with Swann, Chang-Schneider \& Mc. Clarty in Saputri \& Moordiningsih (2016), that the self-concept and self-esteem of students are strongly influenced by experiences in the family, at school, and with peers. The concept of self includes understanding the strengths, weaknesses, abilities, attitudes, and values of goodness in oneself. Meanwhile, self-esteem refers to the process of evaluating the skills and abilities they have.

In elementary school, there are two subjects that are oriented to shape the character of students, among others Islamic religious education and civic education. However, these lessons have a tendency to equip students about valuesthrough subject matter, and are considered unable to encourage the process of internalizing character values in students in everyday life. This is in line with the opinion of Jalaludin (2012), that PPKn (civic education) and religious lessons only involve cognitive aspects, without appreciation, and practice, so don't be surprised if many Indonesians memorize the contents of Pancasila, but do not know how to properly dispose garbage, be honest, have a high work ethic, and establish a harmonious relationship with others.

Understanding the above opinion, the character building of students needs to be integrated in each subject. This is in line with the results of Safitri (2015), that the development of cultural values and character is integrated into every subject in each subject listed in the Syllabus and lesson plan.

Thus, the curriculum 2013 policy which is oriented towards integrative thematic learning, especially in elementary schools can be implemented optimally. The learning process, can be started from the introduction of the values of goodness, then facilitates students to gain awareness of the importance of goodness values, and forms the internalization of good character values in the behavior of students. This can be seen that on the implementation of character education that curriculum 2013 is oriented to developing integrative thematic character education through culture, development, and extracurricular activities that apply in schools toward negative influences from the outside (Kaimuddin, 2014). In addition, character education can affect student's character in fending off unfavorable influences from outside culture (Wulandari, 2017).

Given the importance of character education, many parties demand an increase in the intensity and quality of the implementation of character education in formal education institutions. This demand is based on developing social phenomena as previously described. Therefore, formal educational institutions as an official forum for fostering the younger generation are expected to increase their role in shaping student's personality through increasing the intensity and quality of character education. Thus we felt the need to conduct qualitative study research at SD Negeri 17 Gelumbang, to determine the implementation and synergy of all school components including school 
principals, teachers, students, and school employees in implementing the 2013 curriculum policy on character education for students at SD Negeri 17 Gelumbang.

\section{METHODS}

This paper belongs to qualitative research. The qualitative research is a series of activities capturing information from the normal conditions in the life of an object, connected with a problem, both from a theoretical and practical (Moleong, 2017). The research was conducted at SD Negeri 17 Gelumbang, Putak Village, Gelumbang District, Muara Enim Regency.

The qualitative approach in this paper is descriptive. The descriptive qualitative research is a method of examining the status of group of humans, an object with the aim of making a systematic, factual and accurate descriptive, painting the facts being investigated (Haryono, 2014). The technique used to determine information by observing and interviewing people who are considered to know about the social situation. Determination of the person who is the source of the data is done purposively, that is, chosen with certain considerations. The informants in this study were the principal, teachers, and students. This was chosen because the informants were directly involved in the implementation.

\section{FINDING AND DISCUSSIONS}

The curriculum used in SD Negeri 17 Gelumbang is the curriculum 2013. In the curriculum 2013, character attitude is not only taught verbally, but should being role models. The example of curriculum development at SD Negeri 17 Gelumbang which contains the values of character education is slogan Discipline, Commitment and Responsibilit. The priority is in developing honesty, religion, and discipline by integrating it in the Lesson Plan which is carried out in classroom. Another example is formulating school regulations that contain elements related to character education.

Based on the results of observations and interviews with SD Negeri 17 Gelumbang, that the implementation of character values is by integrating character values into subject matter in the learning process. This is based on the results of interviews with teachers of SD Negeri 17 Gelumbang, explained in the following table.

Table 1. Exemplary Habits by Teachers and Education Personnel

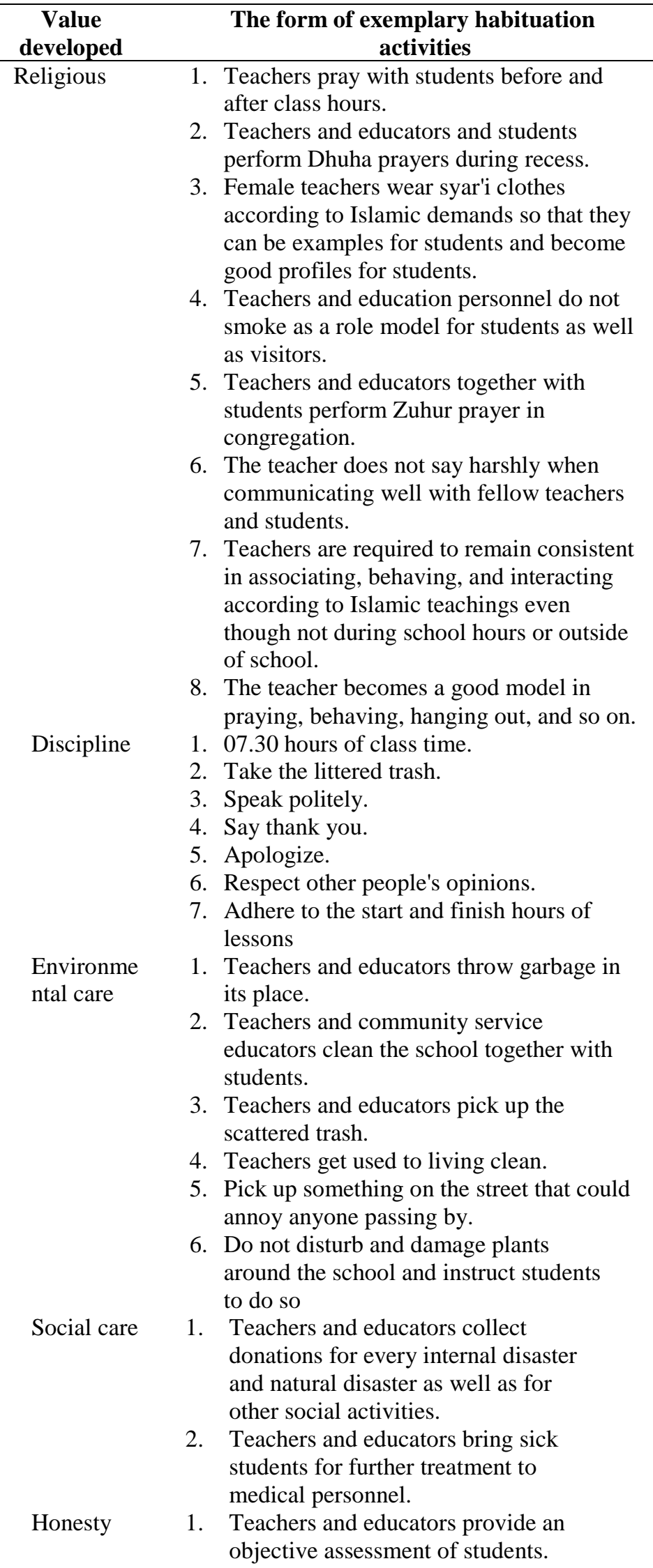




\begin{tabular}{|c|c|c|c|}
\hline $\begin{array}{c}\text { Value } \\
\text { developed }\end{array}$ & $\begin{array}{l}\text { The form of exemplary habituation } \\
\text { activities }\end{array}$ & $\begin{array}{c}\text { Value } \\
\text { developed }\end{array}$ & $\begin{array}{c}\text { The form of exemplary } \\
\text { habituation activities } \\
\end{array}$ \\
\hline \multicolumn{2}{|r|}{$\begin{array}{l}\text { outside the classroom. } \\
\text { The teacher wisely admits mistak } \\
\text { that have occurred. } \\
\text { Teachers and education staff conduct } \\
\text { ceremonies and commemoration of } \\
\text { national and regional holidays with } \\
\text { students. }\end{array}$} & \multirow[t]{2}{*}{ ntal care } & $\begin{array}{l}\text { 1. Get children used to throwing } \\
\text { garbage in its place. } \\
\text { 2. The teacher checks the } \\
\text { cleanliness every day. } \\
\text { 3. Schedule clean pickets for all } \\
\text { students in groups. } \\
\text { 4. Take the trash that is scattered. } \\
\text { Clean Class } \\
\text { 1. Class pickets in groups clean } \\
\text { the class. } \\
\text { 2. Conduct hygiene observations. }\end{array}$ \\
\hline \multirow{4}{*}{\multicolumn{2}{|c|}{$\begin{array}{l}\text { In addition to exemplary habituation, the } \\
\text { implementation of character education at SD } \\
\text { Negeri } 17 \text { Gelumbang was also carried out by } \\
\text { spontaneous habituation in the daily lives of } \\
\text { students and teachers in learning activities. } \\
\text { This implementation can be seen in the table } \\
\text { below. }\end{array}$}} & & $\begin{array}{l}\text { Clean Class } \\
\text { 1. Class pickets in groups clean } \\
\text { the class. } \\
\text { 2. Conduct hygiene observations. } \\
\text { 3. Do not cross walls, chairs, } \\
\text { tables, and so on }\end{array}$ \\
\hline & & Social care & $\begin{array}{l}\text { 1. Collect donations at certain } \\
\text { events. }\end{array}$ \\
\hline & & \multirow[t]{2}{*}{ Honesty } & $\begin{array}{l}\text { 2. Visiting teacher who is sick } \\
\text { 1. Report the findings to the } \\
\text { teacher. }\end{array}$ \\
\hline & & & $\begin{array}{l}\text { 2. Provide a place for proof of } \\
\text { attendance or absence. }\end{array}$ \\
\hline \multicolumn{2}{|c|}{$\begin{array}{l}\text { Table 2. Spontaneous Habituation by Teachers } \\
\text { and Education Personnel }\end{array}$} & \multirow[t]{3}{*}{$\begin{array}{l}\text { Love the } \\
\text { homeland }\end{array}$} & $\begin{array}{l}\text { 1. Using good and correct } \\
\text { Indonesian. } \\
\text { 2. Sing the national anthem at }\end{array}$ \\
\hline $\begin{array}{c}\text { Value } \\
\text { developed }\end{array}$ & $\begin{array}{c}\begin{array}{c}\text { The form of exemplary } \\
\text { habituation activities }\end{array} \\
\end{array}$ & & $\begin{array}{l}\text { every flag ceremony and } \\
\text { commemoration of national }\end{array}$ \\
\hline Religious & $\begin{array}{l}\text { 1. Pray before starting lessons in } \\
\text { congregation in the line. } \\
\text { 2. Every change of lesson hours } \\
\text { students read hamdalah at the }\end{array}$ & & $\begin{array}{l}\text { holidays. } \\
\text { Display photos of the president } \\
\text { and vice president as well as } \\
\text { national symbols }\end{array}$ \\
\hline
\end{tabular}
same time.

3. Students are asked to say greetings before and after the activity, if they meet the teacher, shake hands, talk, and act politely.

4. Students are accustomed to saying thank you, sorry, excuse me, and please.

5. Knock on the door before entering the classroom and after being allowed to enter.

6. Knock on the door before entering someone else's room.

7. Ask permission to use other people's things

Discipline 1. Make notes teachers and students .

2. Hold a row in the morning led by students on duty, then advice from the teacher.

3. At 07.45 WIB all students must be in class and go home according to schedule and students who violate will be penalized.

4. If unable to attend school, there must be a notification letter.

5. Teachers and employees are well-dressed

Environme Clean School Environment

Discipline

Furthermore, the routine habituation activities of SD Negeri 17 Gelumbang based on the results of the interview are described in the following table.

Table 3. Routine Habituation by Teachers and Education Personnel

\begin{tabular}{ll}
\hline $\begin{array}{c}\text { Value } \\
\text { developed }\end{array}$ & $\begin{array}{c}\text { The form of exemplary } \\
\text { habituation activities }\end{array}$ \\
\hline Religious & 1. $\begin{array}{l}\text { Pray before starting lessons in } \\
\text { congregation in the line. }\end{array}$
\end{tabular}

2. Every change of lesson hours students read hamdalah at the same time.

3. Students are asked to say greetings before and after the activity, if they meet the teacher, shake hands, talk, and act politely.

4. Students are accustomed to saying thank you, sorry, excuse me, and please.

5. Knock on the door before entering the classroom and after being allowed to enter.

6. Knock on the door before entering someone else's room.

7. Ask permission to use other people's things

1. Make notes teachers and 


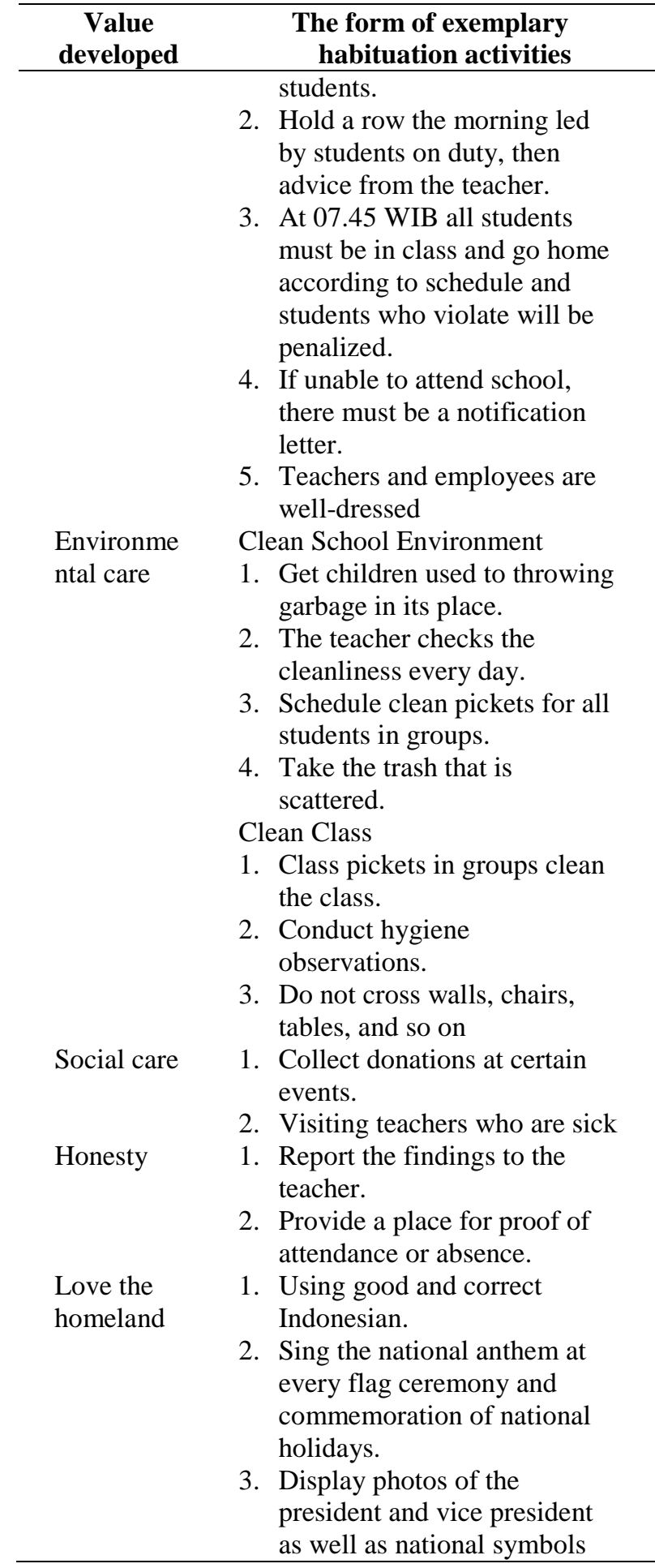

Implementation is an action of a plan that has been prepared carefully in detail. Implementation is usually done after the planning is considered perfect (Syafarudin in Siagian, 2018). Usman in Syafrianto (2015), in his book entitled Context of Curriculum-Based Implementation, the implementation is a signal for activities, actions the existence of a system mechanism, implementation is not just an activity, it is planned to achieve the objectives of the activity.
Haryono (2014), implementation is a process to carry out activities into policy actions from politics to administration. Development of a policy in order to improve a program. Setiawan (2014), in his book entitled Implementation in the Development Bureaucracy implementation is the expansion of activities that mutually adjust the process of interaction between goals and actions to achieve them and requires an effective network of executors, bureaucracies.

From the above understanding it can be concluded that implementation is a system mechanism. The expression mechanism implies not only an activity but an activity that is planned and carried out in earnest based on the reference to certain norms to achieve the objectives of the activity.

The term of character comes from the Latin character, which means psychological traits, personality and morals. The meaning of character is personality in terms of ethical or moral starting points such as someone's honesty. There is a term whose meaning is almost the same as character, personality characteristics which means talents, abilities, and so on, which a person consistently displays, including behavior patterns, physical traits, and personality traits (Fitri, 2012).

Based on the Big Indonesian Dictionary, characters are psychological, moral or character traits that differentiate a person from others (Sumami and Haryanto in Samrin Samrin, 2016). In terminology, character is defined as a human nature in general that depends on the factors of his own life. Character is a mental, moral, or ethical character that characterizes a person or group of people. Character is human behavior related to God Almighty, oneself, fellow humans, environment and nationality, which is manifested in thoughts, attitudes, feelings, words, and actions based on religious norms, law, manners, culture and customs (Fitri, 2012).

The Ministry of National Education character is personal character, morals, or personality which is formed from the internalization of various virtues which are believed and used as a basis for point of view, thinking, behaving, and acting. Meanwhile, according to Darmiyati (2016), an appropriate 
education system to produce a quality society with positive character is humanist, which positions students as individuals and members of society who need to be helped and encouraged to have effective habits, a combination of knowledge, skills, and desire. Meanwhile, the theme of values, despite having social responsibility, can be temporarily suspended. For example, honesty is a value that someone believes in, but that person temporarily suspends commits corruption (Wibowo, 2010).

Character education at an early age in the family aims for formation, at adolescence at school aims for development, while at adult age in college aims for strengthening (Kristiawan, 2015a). According to Supryiningrum, character education has a higher meaning than moral education because it is not just teaching what is right and what is wrong (Cahyaningrum et al., 2017). More than that, character education instills habits about what is good so that students understand to feel and want to do good things. Character education is a broad term that is used to describe the general curriculum and organizational features of schools that promote the development of fundamental valuation in children at school (Yaumi, 2014).

According to Samani \& Hariyanto (2011) in their book, character education is the process of providing guidance to students to become fully human beings who have character in the dimensions of heart, mind, body and feeling and intention. Furthermore, character education according to Salahudin and Alkrienciechie, can be interpreted as moral education or character to develop one's ability to behave well in daily life (Kurniawati, 2018).

Furthermore, according to Muhaimin (2014), character education is a system in instilling good character values to all school members so that they have knowledge and actions in accordance with the values of goodness. Meanwhile, character education according to Zubaedi in Maunah (2015), is all business planning carried out by teachers that can influence the character formation of students, understand, shape, and foster ethical values as a whole.

Furthermore, according to Wibowo in Zulhijrah (2010), character education is an education that is used to instill and develop character in students, so that they have a noble character, so they can apply it in everyday life like at home, at school and in society. According to the Ministry of National Education character education is defined as education that develops and characterizes the nation in students so that they have values and character as their own character, apply these values in their own lives, as members of society, and religious citizens, nationalist, productive and creative.

The results of Suprehiningrum in Cahyaningrum et al. (2017), reveal that there are six criteria that support this success, (1) schools impose values that lead to good character for their students; (2) parents and other communities must be active participants in the implementation of character education; (3) schools need to carry out intensive promotions regarding the implementation of character education in these schools; (4) all members of the school are given the responsibility for and try to implement the character education model; (5) schools help develop community institutions that care about education; and (6) schools provide opportunities for all students to practice moral actions.

Lickona in Sudrajat (2011), states that having knowledge of moral values is not enough to be a human being with character, moral values must be accompanied by a moral character. Included in this character are three components of good character, knowledge of moral, feelings about moral, and moral actions. This is necessary so that humans are able to understand, feel, and at the same time work on the values of virtue.

According to the Lian et al. (2020), the vision of character education is to realize character education as a form of value, moral, and ethical education which functions to develop individual Indonesian citizens with character. noble in thought, attitude, and daily actions, which curricularly really animates and interprets all relevant subjects as well as the socio-cultural system of the world of education so that from within each graduate every type, path, level of education emits noble morals.

The Ministry of National Education describes several objectives of character 
education, developing the values contained in Pancasila, including (1) develop the potential of students to become human beings with good hearts, good minds, and good behavior; (2) building a nation characterized by Pancasila; and (3) developing the potential of citizens to have a confident attitude, be proud of their nation and country and love humanity. The Ministry of National Education aims at character education in a special sense to improve the quality of the implementation and results of education in schools which leads to the achievement of character building in a comprehensive, integrated and balanced manner, according to the competency standards of graduates. Character education according to the Zubaedi in Putry (2019), aims to form a holistic human with character to develop the physical, emotional, social, creative, spiritual, and intellectual aspects of students optimally.

According to Zuriah \& Sunaryo (2018), the objectives of character education are as follows; (1) students understand the values of character; (2) students are able to develop character consistently of the complexity of social life today; (3) students are able to face real problems; (4) students are able to use the experience of good character.

The success or failure in the process of implementing character education is influenced by several factors (1) instinct factors; (2) habit; (3) heredity; and (4) environment (Zubaedi in Maunah, 2015). As explained by Maharani and Mustika (2016) through the guidance and counseling journal, the factors that influence character education can come from oneself or from outside oneself. It can be from the school environment, family, and someone's social environment in the community.

It can be seen that the factors that influence character can come from anywhere. Including coming from the school environment. In addition, Hidayat (2013), the disciplinary factors that are important to pay attention to are awareness, exemplary, and enforcement of regulations. Awareness is the main factor, while modeling and enforcement of the rules are supporting awareness. Without awareness, modeling and enforcement of the rules cannot last long in a person.
According to the Guidelines for the Implementation of Character Education (Kemendiknas: 15-17) the strategy for implementing character education in educational units is an integral part of the school-based quality improvement management program which is implemented in the development, implementation and evaluation of the curriculum by each education unit. In order for character education to be implemented optimally, character education is implemented through the following steps (1) outreach to stakeholders; (2) development in school activities; (3) learning activities; (4) development of school culture and learning activity centers; (5) co-curricular and extracurricular activities; and (6) daily activities at home and in the community

At the planning stage, character sets using various sources, including (1) philosophical considerations Pancasila, UUD 1945, and Law Number 20 of 2003; (2) theories about the brain, psychology, education, values and morals, as well as sociocultural; (3) in the form of experiences and best practices, including figures, superior education units, pesantren, cultural groups, etc (Ismail in Salmiati \& Septiawansyah, 2019). In order for the effective learning process, the role of the teacher as a role model is very important and decisive (Ismail in Salmiati \& Septiawansyah, 2019). In addition, character education could be streng themed by habituation and daily activities at school or any other situastion (Hadiyanto, 2015).

Implementation of character values is compulsory subjects at SD Negeri 17 Gelumbang. First, integrated in the learning process of Islamic Religious Education. Second, it is integrated into the Civic Education learning process. Third, integrated in the Indonesian language learning process. Fourth, integrated in the mathematics learning process. Fifth, integrated in the social studies learning process. Sixth, integrated into science learning. Seventh, integrated in the English learning process. Eighth, integrated in the Physical Education and Health learning process. Integrating character values by instilling confidence in competitions.

\section{CONCLUSION}


Implementation of character values in compulsory subjects by internalizing character values through the learning process; implementation of character values at SD Negeri 17 Gelumbang, is strengthewed by several programs and activities: 1) programmed aims to assist students in carrying out activities, daily discipline, which is carried out regularly whether they are facing difficulties or not; the character of discipline and responsibility instilled by the principal and teacher will set an example for all students; 2) the implementation of disciplinary character education at SD Negeri 17 Gelumbang is also carried out by applying character education to the school curriculum; discipline and responsibility character education at SD Negeri 17 Gelumbang is carried out by integrating the character of discipline and character of responsibility with subjects, school culture and self-development; and 3) the evaluation stage in the implementation of discipline and responsibility character education at SD Negeri 17 Gelumbang is carried out through an attitude assessment for all students as well as jointly between teachers, school principals, and involving students' parents in discussing the problems found. It is hoped that the school will always improve its character education program by maximizing the existing facilities so that in the future SD Negeri 17 Gelumbang will produce student output with character so that it is useful for religion, society and the nation.

\section{REFERENCES}

Cahyaningrum, E. S., Sudaryanti, S., \& Purwanto, N. A. (2017). Pengembangan Nilai-Nilai Karakter Anak Usia Dini Melalui Pembiasaan Dan Keteladanan. Jurnal Pendidikan Anak, 6(2), 203-213. https://doi.org/10.21831/jpa.v6i2.17707

Darmiyati, Z. (2016). Pendidikan Karakter: Grand Design dan Nilai-nilai Target Values. UNY Press.

Fitri, A. Z. (2012). Pendidikan Karakter Berbasis Nilai dan Etika di Sekolah. ArRuzz Media.

Fitria, H., Kristiawan, M., \& Rasyid, A. (2019). The Educational Character on Instruction. Jurnal Opcion, 35(Special Issue 21), 964-979.
Hadiyanto. (2015). Integrasi Pendidikan Karakter di SMP Pondok Pesantren Modern Nurul Ikhlas Kabupaten Tanah Datar Sumatera Barat. Jurnal Ilmiah Ilmu Pendidikan, XV(1), 118-124.

Haryono, D. (2014). Filsafat Matematika. Alfabeta.

Hidayat, H. S. (2013). Pengaruh Kerjasama Orang Tua dan Guru Terhadap Disiplin Peserta Didik di Sekolah Menengah Pertama (SMP) Negeri Kecamatan Jagakarsa - Jakarta Selatan. Jurnal Ilmiah Widya, 1(2), 92-99.

Jalaludin, J. (2012). Membangun SDM Bangsa melalui Pendidikan Karakter. Jurnal Penelitian Pendidikan, 13(2), 1-14.

Judiani, S. (2010). Implementasi Pendidikan Karakter di Sekolah Dasar Melalui Penguatan Pelaksanaan Kurikulum. Jurnal Pendidikan Dan Kebudayaan, 16(Edisi Khusus 3), 280-289. https://doi.org/10.24832/jpnk.v16i9.519

Kaimuddin, K. (2014). Implementasi Pendidikan Karakter dalam Kurikulum 2013. Jurnal Dinamika Ilmu, 14(1), 4163. https://doi.org/10.30738/sosio.v4i2.2982

Kompri, K. (2015). Manajemen Pendidikan: Komponen-komponen

Elementer Kemajuan Sekolah. Ar-Ruzz Media.

Kristiawan, M. (2015a). A Model of Educational Character in High School AlIstiqamah Simpang Empat, West Pasaman, West Sumatera. Research Journal of Education, 1(2), 15-20. https://doi.org/10.31219/osf.io/2q3we

Kristiawan, M. (2015b). Telaah Revolusi Mental dan Pendidikan Karakter dalam Pembentukkan Sumber Daya Manusia Indonesia yang Pandai dan Berakhlak Mulia. Jurnal Ta'dib, 18(1), 13-24. https://doi.org/10.31958/jt.v18i1.274

Kristiawan, M., Nizarani, \& Syamsidar. (2019). Role of school on forming character of z-generation through entrepreneurial skills. International Journal of Scientific and Technology Research, 8(10), 1941-1945.

Kurniawati, A. (2018). Pendidikan Karakter dengan Pendekatan Berbasis Agama dan Budaya Bangsa. Jurnal Ilmiah Pesantren, 4(2), 515-525. 
Lian, B., Kristiawan, M., Ammelia, D., Primasari, G., Anggung, M., \& Prasetyo, M. (2020). Teachers' Model in Building Students' Character. Journal of Critical Reviews, 7(14), 927-932.

Maunah, B. (2015). Implementasi Pendidikan Karakter dalam Pembentukan Kepribadian Holistik Siswa. Jurnal Pendidikan Karakter, 5(1), 90-101. https://doi.org/10.21831/jpk.v0i1.8615

Moleong, L. J. (2017). Metodologi Penelitian Kualitatif. PT Remaja Rosdakarya.

Muhaimin, A. A. (2014). Urgensi Pendidikan Karakter di Indonesia. Ar-Ruzz Media.

Putry, R. (2019). Nilai Pendidikan Karakter Anak di Sekolah Perspektif Kemendiknas. Gender Equality: International Journal of Child and Gender Studies, 4(1), 39-54. https://doi.org/10.22373/equality.v4i1.448 0

Safitri, N. (2015). Implementasi Pendidikan Karakter Melalui Kultur Sekolah di SMP N 14 Yogyakarta. Jurnal Pendidikan Karakter, 5(2), 173-178.

Salmiati, S., \& Septiawansyah, R. (2019). Peranan Administrasi Pendidikan dalam Meningkatkan Profesionalisme Guru Pendidikan Agama Islam (PAI) pada MTs DDI Cilellang Kabupaten Barru. AlMusannif: Journal of Islamic Education and Teacher Training, 1(1), 47-64. https://doi.org/https://doi.org/10.5281/zen odo. 2735066

Samani, M., \& Hariyanto, M. S. (2011). Konsep dan Model Pendidikan Karakter. Remaja Rosdakarya.

Samrin Samrin. (2016). Pendidikan Karakter (Sebuah Pendekatan Nilai). Jurnal AlTa'dib, 9(1), 120-143.

Saputri, M. E., \& Moordiningsih, M. (2016). Pembentukan Konsep Diri Remaja pada Keluarga Jawa yang Beragama Islam. Jurnal Ilmiah Psikologi Terapan, 4(2), 261-268.

Sayer, I. M., Kristiawan, M., \& Agustina, M. (2018). Fairy Tale as a Medium for Children's Character Cooperation Building. Al-Ta Lim Journal, 25(2), 108-
116. https://doi.org/10.15548/jt.v25i2.458

Setiawan, G. (2014). Implementasi dalam Birokrasi Pembangunan. PT Remaja Rosdakarya.

Siagian, K. S. (2018). Implementasi FungsiFungsi Manajemen Kepala Sekolah untuk Meningkatkan Mutu Pembelajaran Guru di MTS Nurul Iman. Universitas Islam Negeri Sumatera Utara.

Sudrajat, A. (2011). Mengapa Pendidikan Karakter? Jurnal Pendidikan Karakter, I(1), 47-58. https://doi.org/10.21831/jpk.v1i1.1316

Syafrianto, E. (2015). Implementasi Pembelajaran Pendidikan Agama Islam Berwawasan Rekontruksi Sosial. AlTadzkiyyah: Jurnal Pendidikan, 6(November), 65-80.

Wibowo, U. B. (2010). Pendidikan dari dalam: Strategi Alternatif Pengembangan Karakter. Jurnal Dinamika Pendidikan, 17(1), 1-14.

Wulandari, H. (2017). Menumbuhkan Pendidikan Karakter Melalui Atikan Purwakarta Pada Pendidikan Anak Usia Dini. Metodik Didaktik. Metodik Didaktik: Jurnal Pendidikan Ke-SD-An, 13(1). https://doi.org/10.17509/md.v13i1.7688

Yaumi, M. (2014). Pendidikan Karakter (Landasan Pilar \& Implementasi). Prenada Media Kencana.

Zulhijrah, Z. (2010). Tantangan Implementasi Pendidikan Karakter di Sekolah. Jurnal Tadrib, https://doi.org/10.21831/cp.v1i3.245

Zuriah, N., \& Sunaryo, H. (2018). Rekayasa Sosial Model Pendidikan Karakter Berbasis Nilai Kearifan Lokal dan Civic Virtue di Perguruan Tinggi. Sosiohumanika: Jurnal Pendidikan Sains Sosial Dan Kemanusiaan, 11(2), 159174. 